\title{
Medical society journals face publishing woes
}

$\mathrm{S}$ everal specialty medical societies say they are scrambling to get their journals out of a sales deal to alleged predatory publisher OMICS International. They say the sale highlights the vulnerability of society journals to upheavals in the publishing industry.

The Canadian Society of Internal Medicine owns the title and copyright of its journal, the Canadian Journal of General Internal Medicine, which was published under contract by Andrew John Publishing until the recent sale to Pulsus Group UK, a new subsidiary of OMICS International based in Hyberdad, India. OMICS is facing charges from the US Federal Trade Commission (FTC) for "deceiving academics and researchers about the nature of its publications and hiding publication fees ranging from hundreds to thousands of dollars," according to an FTC statement.

Canadian Society of Internal Medicine President Dr. Stephen Hwang said, "We've initiated a process to terminate our contract, which was to terminate at the end of the year in any case."

"I think it's very concerning that companies that own and publish journals can be sold and ownership of the journal transferred," said Hwang. "In general, societies need to have safeguards over the control of their journals."

The Canadian Society of Respiratory Therapists has hired a lawyer to help it terminate the contract with Pulsus Group UK for publication of the Canadian Journal of Respiratory Therapy (CJRT), said Carly Brockington, the journal's managing editor. CJRT is quickly making arrangements to publish the next issue of its journal elsewhere. She said she has spoken with publishers who have received calls from the other societies involved, as they try to extricate their journals from OMICS.

But several of the journals in Pulsus' original stable were owned by Pulsus rather than the sponsoring society, creating complications for societies that do not want to stay with the new publisher, regardless of whether they are allegedly predatory or not.

In December 2015, Pulsus sold its four wholly owned journals, including the Canadian Respiratory Journal $(C R J)$, to legitimate open-access publisher Hindawi. It had first offered to sell $C R J$ to its sponsoring organization, the Canadian Thoracic Society (CTS), but Past President Dr. Diane Lougheed said the society was in the midst of a complex corporate change. "We were not in a position to consider purchasing the journal ourselves."

When the journal went to Hindawi, the CTS decided to end its relationship with the journal and issued a release and fact sheet to explain the situation to its members. The society is now looking for a publisher to establish a new journal.

In the meantime, Lougheed said, CTS members do not have a viable Canadian journal in which to publish and the CTS itself has lost a valuable means of communicating to its members. "There will inevitably be a delay in creating a new journal and building an impact factor, which matters to our members, especially junior researchers who are trying to build credibility."

Former Pulsus owner Robert Kalina said he sold to OMICS because of a lack of other options. He says journal publishing is stymied by declining advertising, increasing costs of printing, the impact of open-access journals and the lack of government support for peer-reviewed journals. "What you should also be discussing is why none of the 'non-predatory' publishers were willing to take over our journals," he told CMAJ in an email.

With the loss of Pulsus and Andrew John, there are few Canadian options for journal publishing, said Janet Sutherland, executive director of CTS. That means the journals are bought by "other publishing organizations that don't have the same orientation to the Canadian societies." She added that "Everybody is going to global publishers." - Carolyn Brown, Ottawa, Ont.

CMAJ 2016. DOI:10.1503/cmaj.109-5339 